\title{
Espionage against Poland in the Documents and Analyses of the Polish Special Services (1944-1989) - as Illustrated by the Intelligence Activities of the USA
}

\begin{abstract}
The text is treats of the espionage against Poland in the period 1944-1989. The above analysis has been supplemented with the quantitative data from the period 1944-1984 as regards those convicted for participating in, acting for, and passing on information to the foreign intelligence agencies. The espionage issues were presented on the example of the American intelligence activity, which was illustrated by the cases of persons who were convicted for espionage. While examining the research thesis, the author used the documents and analyses prepared by the Ministry of Internal Affairs, which were in its major part addressed to the Security Service and the Citizens' Militia officers. The author made an attempt at the verification of the following research hypotheses: (1) To what extent did the character of the socio-political system influence the number of persons convicted for espionage against Poland in the period under examination (1944-1989)?; (2) What was the level of foreign intelligence services' interest in Poland before the year 1990?; (3) Is it possible to indicate the specificity of the U.S. intelligence activity against Poland?
\end{abstract}

Key words: espionage, U.S. espionage, intelligence activities, counterespionage, Polish counterintelligence, special services, state security

\section{Introduction}

The aim of this text is to present the level of knowledge among the authorities responsible for the state security and public order about the intelligence activities conducted against Poland in the period 1944-1989. The above issues will be examined against the backdrop of the U.S. espionage. An attempt at the reconstruction of knowledge in this area of interest will be based on an analysis of selected training materials and other documents of the Ministry of Internal Affairs. Additionally, the above analysis will be supplemented with the quantitative data from the 
period 1944-1984 as regards those convicted for participating in, acting for, and passing on information to foreign intelligence agencies. Specific problems related to the U.S. intelligence activity will be supported with examples illustrating the acts of espionage targeted against Poland.

The analysis though will not cover the legal framework for the operation of the Polish special services in the era of the People's Republic of Poland (Polska Republika Ludowa, PRL), nor the historical outline of counter-intelligence and intelligence services in Poland. Moreover, the text will not examine the techniques of invigilation, or the specificity of operational activity in intelligence services.

It should be noted here that a great number of reports prepared by the Ministry of Internal Affairs or the Ministry of National Defence were destroyed during the political transition process at the turn of 1989 and 1990; however, it should not be associated solely with the destruction of records describing the processes of acquiring agents internally or abroad by the Polish special services in the PRL era (e.g. the documentation on training the candidates for informants or agents' recruitment). Thus, this analysis will be limited in terms of the quantitative data related to the persons convicted in Poland for espionage and the information on these issues included in the training materials prepared by the Ministry of Internal Affairs for the officers of the Security Service of the Ministry of Internal Affairs (Służba Bezpieczeństwa, SB) and the Citizens' Militia (Milicja Obywatelska, MO).

As regards the subject matter of this analysis and the aim of the research, the following questions have been raised: (1) To what extent did the character of the socio-political system influence the number of persons convicted for espionage against Poland in the period under examination (1944-1989)?; (2) What was the level of foreign intelligence services' interest in Poland before the year 1990?; (3) Is it possible to indicate the specificity of the U.S. intelligence activity against Poland?

\section{Research methodology used in the analysis of the sources}

The access to the training materials prepared by the Ministry of Internal Affairs for the officers of the Security Service was possible thanks to the prior studies of the issues of information security held on our own. The analysis of selected documents was supplemented with open interviews with former Security Service officers. However, the above mentioned open interview should be classified as an example of "oral history" 
in its broadest meaning; it was carried out solely to reproduce the awareness and the mindset in the area of conducted research (including the perception of the training materials prepared by the Ministry of Internal Affairs for the Security Service officers during their work before 1990). This interview helped to take a critical stance on the ideological content of these materials as well as on the practices of the Security Service officers - it did not constitute a matter for detailed presentation in the text.

The analysis was mainly based on the training materials prepared by the Ministry of Internal Affairs, which are listed in the References. What should be taken into account is the type of the documents whose characteristic features (e.g. the date of issue, authorship, title of the publication) might be missing by author's discretion. The lack of basic "biographical elements" follows from the fact that the author of the text had access only to the documents which were destroyed partially by the officers of the Ministry of Internal Affairs themselves - it is then plausible that there exist the same documents with full "biographical data" coverage. A potential source of such documentation might constitute the archives of the Institute of National Remembrance, whose aim is to: (1) handle the documents by the Communist State Security Bodies (1944-1989), (2) prosecute the communist and Nazi crimes, (3) organise educational activities. Of paramount importance is here the Office for the Preservation and Dissemination of Archival Records - it collects, keeps, secures, elaborates on, records, and makes documents available.

What should be considered then is the credibility of the documents prepared by the Ministry of Internal Affairs; the same holds true for the analysis of convictions for espionage. Certainly, the training materials prepared by the Ministry of Internal Affairs were influenced by the ideology of the then political system and its specificity. As an example here may serve the materials referring to the possible German revisionism as regards Poland's western border. In the case of criminal judgements for espionage there could have been convictions for espionage which, considering present legislation and judicature, would never have taken place. Undoubtedly, it remains an open question whether the authenticity of the documents prepared by the apparatus of the socialist state's repression could be trusted (Brzechczyn, 2012, pp. 53-77). Analysing the documents from the PRL era one should act wisely and moderately; in methodology one should pay their attention to the fact that two paradigms, i.e. narrativism and positivism, are not devoid of drawbacks (Brzechczyn, 2013, pp. 513-518; Brzechczyn, 2006, pp. 37-53). 


\section{Overall analysis of the intelligence activity against Poland (1944-1989)}

In the period 1944-1984, the number of convicts for espionage against Poland exceeded 2160 persons; however, it should be stressed that we are talking about the statistics concerned with convictions and not with the established cases of espionage either for foreign intelligence services or on behalf of the so-called "Western reactionary centres" (Cf. Figure 1) (Informant, 1986). The sheer fact of establishing an act of espionage and convicting for espionage to some extent marks a defeat of particular services, as it means that those persons could not be recruited or used as "reversed agents". However, it can be assumed that in some cases the security bodies were not interested in acquiring new agents, as the elimination of possible threats to the State's security and public order was considered as more important. Also, the figures provided by the Ministry of Internal Affairs in the period in question are controversial, which can be derived from the following facts: (1) the lack of detectability of espionage crimes against Poland, as well as (2) the possibility of acquiring the unmasked agents to fight against the intelligence services for which they had previously worked. Moreover, the quantitative data point to the fact that the number of convictions in the 1940s and '50s was overrepresented. Furthermore, it should be emphasised that an important factor leading to this misinterpretation of the quantitative data is the belief among the researchers themselves that the number of "real" spies in the period in question could amount to 350-400 persons (Piecuch, 1996, pp. 406-407), although one should rather support the view that the number of "real" spies was smaller, but it is hard to prove, as it is impossible to provide the exact data. Such data could be obtained only after the analysis of the materials from the trials of particular persons.

The greatest number of spies convicted in the period 1944-1984 worked for the USA (33.2\%), the UK (19.9\%), France (10.1\%), West Germany $(9.5 \%)$, Sweden $(0.7 \%)$, and for the so-called "western reactionary centres" $(21.3 \%)$. The remaining cases, i.e. more than $5 \%$, referred to the instances of espionage for other countries. What deserves our attention is the number of convictions for espionage in the period 1946-1956, which reached nearly $82 \%{ }^{1}$

${ }^{1}$ Own calculations based on the data of the Ministry of Internal Affairs from 1986. 


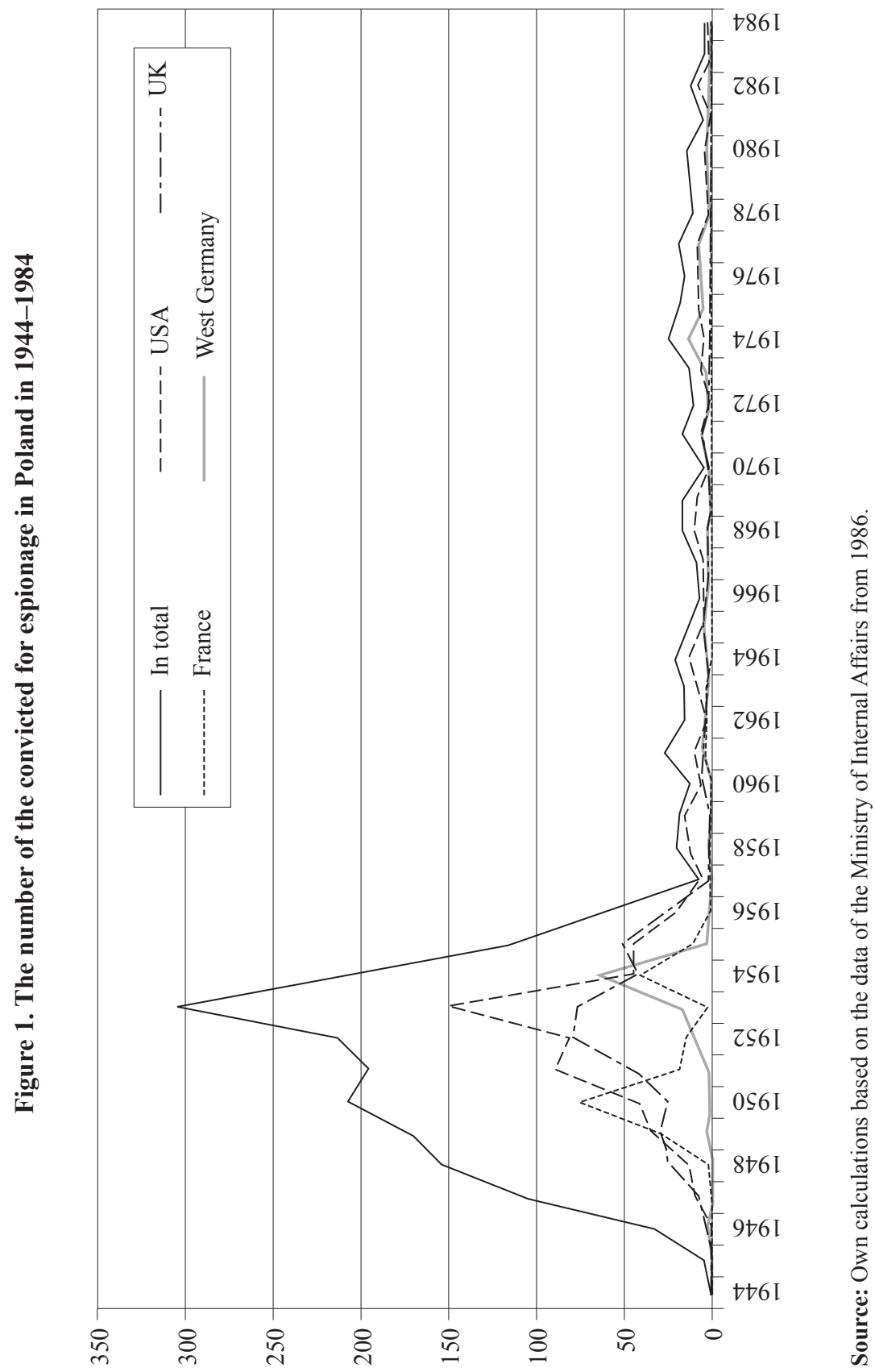


Then what was the phenomenon of the period 1946-1956? In the first place, it is the peculiar political situation of all countries that fell under the influence of the USSR. By 1953, they had been left with strong imprint of Stalin's ideology. In 1946 the USSR, faced with serious economic underdevelopment, embarked on another 5-year plan; the society was subjected to increased control mechanisms and to another wave of ideological indoctrination. The model of Stalin's state was reproduced in the so-called people's democracies, i.e. countries that had become dependent on the USSR, including Poland (Czubiński 1998, pp. 260-270). Internal policy was also influenced by external factors, such as the "Cold War" or Poland's political structures operating in exile. Moreover, in this period the communist authorities were still engaged in the fight against the underground independence movement (e.g. Polish underground anticommunist organisation Freedom and Independence or the Ukrainian Insurgent Army). There was also an urgent need for effective mechanisms guaranteeing the successful introduction of socio-economic reforms, e.g. the agricultural reform (Cf. Luczak, 2011, pp. 53-58; Jakimek-Zapart, 2008, pp. 95-103). Another factor could be the specificity of the practice of the security bodies and courts as well as the specific legal situation ensuing from the prolonged application of the Polish Armed Forces Penal Code.

Moreover, of big importance was the development of security agencies in Poland, which remained under the direct influence of the USSR for a long time (int. al. through the supervision executed by the Soviet advisors). The Polish security apparatus was of the Soviet pedigree - the Ministry of Public Security (Ministerstwo Bezpieczeństwa Publicznego) was established in 1945 and thus replaced the Department of Public Security (Resort Bezpieczeństwa Publicznego), which had been formed under the auspices of the Polish Committee of National Liberation (the "puppet" government set up de facto in Moscow in July, 1944).

Beginning with the year 1945, Poland witnessed an intensified development of the security apparatus, inter alia through the establishment of regional units - the Voivodeship Offices of Public Security (Wojewódzkie Urzędy Bezpieczeństwa Publicznego). During the years of Stanisław Radkiewicz's term (1944/1945-1954), the Department set up 14 Voivodeship Offices of Public Security and over 200 poviat units. Moreover, the security apparatus included: the Polish People's Army (Ludowe Wojsko Polskie), under the command of the Marshal of Poland and USSR, the Minister of National Defence of the Republic of Poland and the People's 
Republic of Poland Konstanty K. Rokossowski; the Border Protection Troops (Wojsko Ochrony Pogranicza), whose first Commander-in-Chief was G. Czerwiński - major general of the Soviet Army, brigadier general of the Polish Armed Forces, who returned to the USSR in 1947; the Internal Security Corps (Korpus Bezpieczeństwa Wewnętrznego), which was operating in the period 1945-1965 and whose aim was to fight against the Polish underground independence movement as well as the Ukrainian and German military organisations; the Citizens' Militia (Milicja Obywatelska), which was operating in the years 1944-1990; and the Volunteer Reserve Militia (Ochotnicza Rezerwa Milicji Obywatelskiej, ORMO), which operated during the period 1946-1989 (Królikowski, 2010; Prochwicz, 1995; Paczkowski, 1993, pp. 1-9; Paczkowski, 1992a, pp. 3-7; Paczkowski, 1992b, pp. 378-383).

Along the political changes within the communist system, there were introduced other reforms of the security apparatus. And thus, in 1956, the Department of Security (Urząd Bezpieczeństwa, UB) was transformed into the Security Service, which remained under the supervision of the Ministry of Internal Affairs. It is impossible to analyse here all the changes (these can be found in the synthetic studies by the Institute of National Remembrance); however, it is worth mentioning that while analysing espionage, particular divisions/departments of the Security Service appear as highly important: No. 1 - intelligence, No. 2 - counter-intelligence, No. 3 - intended to fight against any subversive activity on the territory of Poland (Apparatus, 2005, pp. 19-75; Apparatus, 2006, pp. 7-31; Apparatus, 2008, pp. 9-59; Faces, 2010, pp. 11-32). Moreover, the problem of espionage was handled by armed special services: (1) established in 1957, the Military Internal Service at the Ministry of National Defence (Wojskowa Służba Wewnętrzna Ministerstwa Obrony Narodowej) replaced the Main Directorate of Information of the Polish Army (Główny Zarząd Informacji Wojska Polskiego) as a military counter-espionage organ, (2) the Board of the $\mathbf{2}^{\text {nd }}$ Division of the General Staff of the Polish Armed Forces as a military intelligence organ (Koj, 2007, pp. 80-87).

To illustrate the point, the scope of responsibilities of the officers from the $2^{\text {nd }}$ Division of the Security Service included: (1) organisation and implementation of counter-intelligence (prevention and detection of espionage and diversion activity), (2) operational supervision over various facilities and communities, (3) work with informants (including the organisation of contact points), (4) systematic reconnaissance of the com- 
munities related to the foreigners, (5) co-operation with passport control points in order to conduct counter-espionage selection (persons arriving in and leaving PRL), (6) operational safeguard of the foreigners staying in Poland, (7) flow of information on the protected facilities of key importance for the security issues (including the military complex of the People's Army and the Soviet Army). The interviews with former Security Service officers revealed that at the lowest level (the Regional Offices of Internal Affairs) a great number of operational actions (e.g. the control over strategic facilities) were feigned, which was due to the fact that the officers had to report to their superiors and show their competence. In the 1980s, in the PRL era, it was hardly possible to Report multiple instances of counter-espionage threats at the level of communes [Pol. administrative units of 'gmina'], hence the Security Service officers fabricated stories about feigned threats (this phenomenon should be taken into account in the analysis of the operational documents of these services). ${ }^{2}$

\section{An analysis of intelligence activity as illustrated by the case of the USA}

Most importantly, it should be noted that of all Western countries, it was the USA that disposed of the largest intelligence capacity, which is why many pointed to the "massive" character of U.S. intelligence activity. The training materials prepared by the Ministry of Internal Affairs confirm that in the area of intelligence activity it is the NATO countries, with the USA in the lead, which were the most active diplomacies in this respect. The American intelligence was treated as "the main tool of politics in the imperial circles, which opposed the policy of détente on the international stage" (Immunities, pp. 19-21; Certain features). The main examples usually given to illustrate the point and prove the existence of activities threatening the international security and the security of particular countries include the interventions in Cuba, Laos, Vietnam, and Latin America (Certain features).

Moreover, the American intelligence service was believed to actively operate in the Federal Republic of Germany (FRG) and West Berlin. ${ }^{3} \mathrm{Ob}-$

${ }^{2}$ Synthesis of tasks based on the open interview with the former Security service officers.

3 Until the ratification of the Treaty of Warsaw (on the normalisation of relations between the People's Republic of Poland and the Federal Republic of Germany) in 
viously, the sheer fact of the presence of the Americans in the Federal Republic of Germany ensued from the introduction of allied-occupied zones in this region in the 1940s. However, the American activity in the following years was related to the establishment on the German territory of a quasi operational centre (a kind of a "starting point" for intelligence activities) against the socialist states. According to the archives of the Ministry of Internal Affairs, in the period between 1940s and 1960s, on the territory of the Federal Republic of Germany, there were operating over three hundred intelligence units. As regards the activity of the American intelligence services in Poland, there are available the quantitative data, presented in this text.

What should be pointed out is the common practice of getaways from the communist Poland to the Federal Republic of Germany. Those who managed to reach the FRG, or directly the West Berlin, stayed for a while in the refugee camps, which were controlled by the intelligence services of the Western countries. As an example here may serve an escape of Augustyn D. who, after reaching the Federal Republic of Germany, was allegedly interrogated by the British, French, and finally the American intelligence services, to be subsequently recruited by the latter. Following his recruitment, Augustyn D. was to be trained in the area of drawing sketches and detecting the troops of the Polish Armed Forces and the Soviet Army. Augustyn D. was captured, while he was crossing the FRGGDR (German Democratic Republic) border in 1960, and, subsequently, was sentenced to five years in prison beginning with 1961 (Materials, No. 6007/III). Similar was the case of Edward A., who joined the "Valka" refugee camp in Nuremberg. In 1955, Edward A. agreed to co-operate with the American intelligence service, which resulted in his attempt to cross the FRG-GDR border, organise a spy ring and gather military information. He was arrested by the GDR border guards and handed over to the Polish authorities, who sentenced him to 13 years of imprisonment (Materials, No. 6830/II). Another example is Aleksander A., who was an officer on vessels flying the FRG and Swedish flags in 1960s and "70s. In 1963, Aleksander A. stayed in the "Camp Cing" refugee camp near Oberursel in FRG. During his stay in the camp, he allegedly passed on, to two American intelligence officers, information on military facilities, including the location of a torpedo platform. Aleksander A. was charged

1970, Poland officially used the name of the German Federal Republic (Niemiecka Republika Federalna, NRF) when referring to the German state. 
with espionage and sentenced to 6 years in prison in 1975 (Materials, No. 15429/II; Materials, No. 7838/III).

Most naturally, the Polish counter-intelligence service was interested in diplomatic posts of the Western countries. It was clear that all diplomatic posts of the capitalist countries gathered information on the sociopolitical situation, including the defence issues (Immunities, pp. 12-22). Polish citizens themselves were a natural source of information, hence a key role in intelligence activity against Poland was played by personal contacts or attempts at establishing such contacts by diplomats. The activity of persons gathering information on the military issues (the state defence, the functioning of the Warsaw Pact, new military technologies, rocket stations, military training areas, the Soviet Army troops) was regarded as the most detrimental. In the case of diplomatic posts, this kind of information fell in the area of interest of military attachés and certain civil diplomats, some of which were full-time intelligence service agents (Immunities, pp. 12-21; Certain features, pp. 33-34). Passing on information and co-operation was also possible in diplomatic posts outside Poland, which was the case of Gerard B., who as an employer of the Polish Ocean Lines turned to the U.S. embassy in Rotterdam, offering his intelligence services. Gerard B. gathered and passed on military information from the territory of Poland, the People's Republic of China, the People's Republic of Korea, and Hungary to the U.S. embassy in Rotterdam, for which he was sentenced to 10 years of imprisonment in 1968 (Materials, No. $11371 /$ II).

The most famous case of recruitment outside Poland was that of Ryszard J. Kukliński. According to Kukliński's account, his recruitment began with his letter to the military attaché at the U.S. embassy in Bonn, which led to his meeting with the American special services in the Hague, in 1972. The issue of the place of recruitment is also disputable, as it is believed that Kukliński could have been recruited by the Americans during the period 1967-1968, when he served in the International Commission for Supervision and Control over the Geneva Accords in Vietnam. Some speculate that Kukliński, who was supported by the Soviet officers in terms of his military career in Poland, was manipulated by the GRU in their operational game (Walenciak, 2014). It is estimated that since the beginning of the 1970s till the beginning of the 1980s Kukliński passed on to the Americans circa 35,000 documents, mainly the strategic plans and organisational documents of the Warsaw Pact, including the documents on Poland's defence during the conflict with the West- 
ern bloc. The range of topics covered in the documents passed on to the Americans is still thoroughly analysed and widely discussed (Puchała, 2012, pp. 164-184; Nurowska, 2004). Irrespective of any ethical evaluation of Kukliński's doings, due to his espionage activity it was not only the security and the defence of PRL at stake, but also the security of the whole Polish society, should any military confrontation with the NATO states have occurred. By the judgment of the Military Chamber of the Supreme Court of 23 May 1984 Kukliński was sentenced in absentia to death, deprived of public rights for a lifetime, whereas his property was subjected to total confiscation. Kukliński was convicted for high treason in accordance with Article 122 of the then Penal Code (pursuant to the Constitution of the People's Republic of Poland, Art. 93, Item 2, it was the greatest crime committed against the State). It is worth emphasising that Kukliński was a Colonel of the Polish Armed Forces and a Head of the Strategy and Defence Planning Division of the General Staff of the Polish Army. In 1995, partially thanks to the USA that exerted pressure on Poland in relation to the procedure of accession into the structures of NATO, the Supreme Court set aside the conviction of 1984 and the case was submitted for reconsideration by the prosecution of the Warsaw Military District. Later on, Kukliński was rehabilitated as an officer of the Polish Armed Forces. The justification for the discontinuation of the proceedings is secret - the grounds for it might have been the "state of higher necessity"; however, Kukliński's defender pleaded that the crime, in line with Article 122 of the then Penal Code, is not presently penalised (Krajewski, 2014, pp. 134-136).

There were other instances of getaways of the PRL apparatus' officers, one of which was the case of Władysław Tykociński (aka Tykotzinor), who deserted in 1965 (being at the time the Head of the PRL Military Mission in the West Berlin, the Minister Plenipotentiary, the Colonel of the Polish Armed Forces, and till 1944 the soldier of the Red Army). After his escape, he was stationed at the "Camp Cing" refugee camp, where he was interrogated by the CIA officers. The information he passed on enabled the FRG authorities to charge other persons for their intelligence activity. By the Military Court judgment he was sentenced in absentia to death in 1966 (Materials, No. 6399/III). He died in circumstances that were never clarified in the USA, two years after his getaway.

It is worth mentioning that apart from the cases of Kukliński and Tykociński there were other instances of getaways and espionage among military officers. Five colonels of the Polish Army escaped from Poland, 
who (apart from the above two) were as follows: Paweł Monat (the officer at the Board of the $2^{\text {nd }}$ Division of the General Staff of the Polish Armed Forces, the head of the Military Attachés Department, a former soldier of the Red Army), Klemens Nussbaum (the deputy head of the military studies department at the Warsaw University of Technology), and Włodzimierz Ostaszewicz (the head of the Office of the Plenipotentiary of the General Staff for Special Affairs). Poland also witnessed getaways of two generals (Izydor Modelski and Leon Dubicki) and several dozens of other military officers. In total, in the period 1944-1990, 61 military officers escaped to different countries, including pilots who hijacked planes (Pióro, 1999, pp. 124-139).

A valuable source of information for the USA was P. Monat, who had a thorough knowledge of the Polish intelligence service as well as a great familiarity with the Party apparatchiks - his wife was an adopted daughter of A. Zawadzki (the Chairman of the Council of State of the Republic of Poland). P. Monat escaped in 1959 during his work leave in Yugoslavia. On his journey, he met with the Czech military attaché, F. Tisler, who also escaped to the USA; it is assumed that they had co-operated for a long time with the U.S. intelligence service (Pióro, 1999, pp. 124-139; Dulles, 2006, pp. 137-139). P. Monat was sentenced in absentia to death for high treason and deprived of public and honorary civil rights for a lifetime (Materials, No. ZS-3977).

Another person who used his trip to Yugoslavia to organise his getaway was K. Nussbaum; he escaped with his family in 1968. He travelled through Italy and his ultimate destination was Israel. The case of K. Nussbaum was significant, as his wife Stanisława Zawadecka-Nussbaum was a PRL Sejm deputy and the Secretary of the National Unity Front (i.e. the coalition of the three legal communist parties). However, in this particular case there is no vital information on their co-operation with the USA (Pióro, 1999, pp. 124-139).

Another colonel who fled during his stay abroad was W. Ostaszewicz. His escape took place during his apparent holiday sojourn in Yugoslavia and Greece, where he was supposed to stay with his family in 1981; instead, he made a breakthrough from Austria to Great Britain and finally landed in Canada. By the Military Court judgment Ostaszewicz was sentenced to death, deprived of public rights for a lifetime, and his property was subject to confiscation (Catalogue, 2014). It should be noted that while Włodzimierz Ostaszewicz fled in September 1981, his son, Marek (a consular attaché at the Consulate-General in Toronto) was charged 
with passing on classified information constituting a State Secret to the Canadian and American special services, in October 1981. By the Military Court judgment Marek Ostaszewicz was sentenced in absentia for espionage to 15 years of imprisonment and 8 years of the deprivation of public rights (Materials, No. 7385/III). Moreover, in relation to the case of R. J. Kukliński, two facts remain controversial: (1) it was Włodzimierz Ostaszewicz who recommended Kukliński for his mission in Vietnam, towards the end of 1960s; (2) Włodzimierz Ostaszewicz and Ryszard Kukliński used to be neighbours, when they lived in Warsaw.

Also, members of the staff of the Ministry of Internal Affairs and the Ministry of Foreign Affairs made attempts at instigating co-operation with the USA. Janusz Kochański might serve as an illustration of the point; he used his diplomatic passport to reach Copenhagen, from where he refused to return to his country. Subsequently, he went to the USA. Kochański is an interesting case, as he was a member of the staff of the First Department of the Ministry of Internal Affairs (intelligence), the director of the Department of Polish Diaspora at the Ministry of Foreign Affairs, as well as the resident of the intelligence service in Stockholm and Oslo. By the Military Court judgment he was sentenced in absentia to death in 1968 (Materials, No. 4063/III; Pawlikowicz, 2004).

Another noteworthy case is that of Bogdan Walewski, who worked for the Permanent Mission of the People's Republic of Poland to the United Nations in New York. According to the information of the Ministry of Internal Affairs, he co-operated with the American intelligence service in the years 1959-1981. He was recruited by the Canadians on behalf of the U.S. intelligence. However, it should be noted that in 1954 he was recruited by the KGB during his studies at the Institute of International Relations in Moscow. Most probably, his recruitment for the USA in Vietnam was part of his task commissioned by the KGB. He performed crucial diplomatic functions - he was the Chief of the Diplomatic Protocol, the vice-Director of the Polish Institute of International Affairs, the First Secretary of the Polish Embassy in Moscow, the Head of the Immunities and Privileges Department at the Ministry of Foreign Affairs. By the Military Court judgment of 1982 he was sentenced to 25 years of imprisonment, 10 years of deprivation of public rights and a fine. In 1985, in Berlin, Walewski was exchanged for the Polish agent, M. Zacharski (Materials, No. 7434/III).

It should also be mentioned that there were instances of Polish citizens who contacted various diplomatic posts on the territory of Poland. Such 
was the case of Andrzej B., who went to the U.S. embassy in Warsaw in 1978. In 1979, he was sentenced to 13 years of imprisonment for the cooperation with foreign intelligence services, which consisted in passing on the information on the defence of the People's Republic of Poland (Materials, No. ZS-4502).

In general, the diplomats of Western countries in Poland were granted freedom of movement, with the obvious exception of the so-called "closed areas", e.g. the military training grounds. However, it should be emphasised that in response to the decision of the U.S. government of 1963 introducing restricted areas for the Polish diplomats in Washington as well as for the Polish consulate staff in Chicago and the representatives to the United Nations, the Polish government too prohibited the passage of the American diplomats to certain areas in Poland (Immunities, pp. 12-21). The instructions for the officers of the uniformed and special services of the Ministry of Internal Affairs pointed to the necessity of counteracting the attempts made by foreign diplomats to enter the restricted industrial facilities and the secured premises as well as of preventing the persons with diplomatic immunities and privileges from making photos (Gliński, 1958, pp. 131-132). Moreover, what was pointed out was the necessity of the Citizens' Militia's co-operation with the Security Service as regards gathering information on the arrival of each and every foreigner and, in particular, on the activities undertaken by the diplomats, inter alia on the presence of diplomatic corps vehicles in certain areas (Cf. Immunities, pp. 22-33; Letter, 1963; Order no. 8/57, 1957). A statutory registration requirement was an effective mechanism of controlling foreigners; it stated that a foreigner had to register within 24 hours from their arrival in Poland and, in addition, they had to inform the competent authorities of each and every change in their place of residence (holders of immunities or diplomatic privileges were exempted from this obligation) (Uldanowicz, 1960, pp. 112-115).

According to the analyses of the Ministry of Internal Affairs, the U.S. embassy in Warsaw sheltered the permanent residency of the American intelligence service. The residency was to mirror the significance of particular special services in the USA, and thus it was speculated that the embassy covered for the representatives of the CIA (Central Intelligence Agency), the DIA (Defence Intelligence Agency), the NSA (National Security Agency), the INR (State Department Bureau of Intelligence and Research), and other institutions (Affet, 1978; Pleskot, 2013a, pp. 332-340). However, the greatest merit was ascribed to the CIA, which was due to its 
institutional backing in the USA - the CIA was the secret service which co-ordinated the operations of all intelligence agencies (Pleskot, 2013a, p. 335).

It was mentioned earlier that the presence of the Americans in FRG was vital for the Polish counter-intelligence. It follows from the fact that a great number of agents captured and sentenced for espionage on behalf of the USA were trained in the training centre in Frankfurt am Main. According to the training materials of the Security Service, Frankfurt am Main was considered to be the regional centre (or branch) of the CIA, which was to co-ordinate specific residencies in the region, including the territory of Poland, the West Berlin, Hamburg, Munich, Stuttgart, and Vienna (Pleskot, 2013a, p. 336). However, after the analysis of the quantitative data of the Ministry of Internal Affairs as regards the convictions for espionage in the period 1944-1984, it becomes clear that part of the Polish citizens recruited on the territory of FRG went through the training procedures not only in Frankfurt am Main, but also in other centres, e.g. the West Berlin. Thus, the West Berlin was the area of possible organised intelligence operations targeted at the encouragement of the Polish citizens to co-operate, which in turn constituted an area of interest for the Polish intelligence and counter-intelligence services. The West Berlin was also a destination point of the Polish citizens' getaways, which constituted a natural source of agents' recruitment.

According to the data of 1988, the residency in the U.S. embassy in Warsaw consisted of 32 staff members, which constituted $55 \%$ of the whole embassy's operational personnel. The staff workers and the official civil services employees amounted to 17 persons in total. The residency had its representatives in the culture and press division as well as in the economic, political, and consular departments. The military officers of the special services joined the ranks of the military attachés, the telecommunications, political, and economic divisions as well as the science and technology department. A group of residents was supported by persons who arrived in the embassy for short sojourns (Information, 1988).

The Ministry of Internal Affairs differentiated 6 directions in the activity of the embassy's residency: (1) defence, (2) political issues (the functioning of the PRL apparatus), (3) the activity of the political opposition, (4) the economy, (5) Poland's inter-allied relations, (6) the activity of the Church in Poland (Information, 1988).

It is obvious that it was in line with its counter-espionage activity that the $2^{\text {nd }}$ Division of the Security Service attempted to acquire foreign dip- 
lomats for co-operation. However, the materials of the Security Service on their activity targeted at the recruitment of a diplomat-mole are infinitesimal as compared to the documents on other types of recruitment (Pleskot, 2013a, pp. 194-202). It might be the result of: (1) the poor effectiveness of the Security Service, (2) a possible destruction of operational files and/or thematic files on the recruited diplomats and unmasked diplomatic posts, (3) the fact that these diplomats were handed over to the USSR special services residing on the territory of Poland.

As regards the first case, it might have ensued from the overall difficulty with the recruitment in the diplomatic circles. A frequent tool that facilitated recruitment was concocting a provocation. Also, it was not necessary to get through to diplomats directly; it was a common practice to engage the prostitutes co-operating with the Security Service, who gathered information indirectly. For instance, it is assumed that the "B" Division of the Security Service performed its operational techniques in hotels of higher standard, i.e. where foreigners were likely to stay.

The second case might be backed by open interviews with the former Security Service officers, who admitted that the documentation on the recruitment of operational contacts and clandestine collaborators in diplomatic posts could have been and had been in fact destroyed (e.g. "operational files", "thematic files" on specific embassies). However, the sheer fact that the files were destroyed does not necessarily mean that it is now impossible to restore part of the information. Most probably, one would need to conduct a detailed analysis of the remaining records of "thematic files" (on the diplomatic posts) and/or "personal files" - which, unlike the "operational files" and "compound files", were not destroyed (Cf. Zając, 2006, pp. 21-36).

As regards the last case, it should be pointed out that on the territory of Poland there was the residency of the Soviet intelligence service, which on its own conducted operational games involving foreigners; thus, it cannot be ruled out that this might be the underlying cause for the lack of information on the recruitment of the diplomats in PRL. Similarly, it cannot be excluded that because of the co-operation of the Polish intelligence service with the Soviet one, the recruited clandestine collaborators were handed over to the Soviet services. Moreover, the Polish intelligence service recruited foreigners and diplomats outside the territory of Poland, e.g. through the activities under the cover of the "Unitra" company. 


\section{Conclusion}

The text analyses the intelligence activity against Poland in the period 1944-1989. The paper also contains a case study, i.e. an analysis of the American intelligence service activity held against Poland. While examining the research thesis, the author used the documents and analyses prepared by the Ministry of Internal Affairs. In order to best illustrate the point, the author presented a number of cases of persons who spied for the USA, which was possible thanks to the analysis of the training materials of the Ministry of Internal Affairs directed to the officers of the Security Service and the Citizens' Militia.

The text tackles the following issues: (1) To what extent did the character of the socio-political system influence the number of persons convicted for espionage against Poland in the period under examination (1944-1989)?; (2) What was the level of interest of the foreign intelligence services in Poland before the year 1990?; (3) Is it possible to indicate the specificity of the U.S. intelligence activity against Poland?

1) The analysis of data indicates that the period 1946-1956 witnessed a great number of convictions for espionage, which is often associated with the peculiar political situation in Poland of that time. Up to 1953, the countries of the Eastern bloc had reproduced the Stalin's system, which only ceased due to the death of Stalin himself. Since then, the communist systems gradually transformed into the system of nomenklatura. Irrespective of these changes, Poland still witnessed a wave of repressions, which resulted from the threats continuously looming over the communist authorities - combating the anti-communist underground movement, fighting with the Ukrainian Insurgent Army, the Polish government-in-exile, possible revisionism of borders, social discontent related to the socio-political reforms. Hence, a great number of convictions for espionage at that time could be ascribed to purely political sentences. Moreover, equally significant was the fact that the then judicial practice was preoccupied assessing negatively any contacts and relations with foreigners. This excessive number of convictions could ensue from other criminal-law provisions, which applied with respect to the crimes against the State, including espionage. What is also important is the fact that in the Stalin's period the judiciary personnel acquired their skills and qualifications through intensive courses in law with the predominant spirit of the theory of evidence and law by Andrey Vyshinsky. Additionally, by the decree of 1944 the $P e$ nal Code of the Polish Armed Forces was introduced; the code envisaged 
the increase in the number of offences classified as penalised with death penalty, whereas the high treason was subject to the military jurisdiction (the civilians were prosecuted in military courts till 1955; the espionage, however, still stood under the military jurisdiction). In 1946, there was introduced the Decree on particularly dangerous crimes in the period of the State's recovery, which was later called a Small Penal Code.

2) The interest that foreign intelligence services expressed in relation to Poland was similar to the one they had in all countries of Eastern and Central Europe. In the case of Poland, it should be noted that foreign intelligence services recruited Polish citizens who had previously stayed abroad and after WWII returned to their home country. The services also gathered information from Poles staying in immigrant camps (e.g. in FRG). The activity of the American intelligence service on the territory of FRG and West Berlin played a key role. The documents of the Ministry of Internal Affairs pointed to the global range of this activity, e.g. through the recruitment of Polish sailors in the ports of the Netherlands, Japan, etc. In line with the development in the 1970s, espionage, which had so far concentrated on the defence and strategic sectors, became focused on science and technology of the People's Republic of Poland. The acquisition of collaborators in academic circles was much easier, as PRL opened to academic exchange. Due to the system of visas, the process of candidate selection for intelligence services (e.g. the American) began in embassies. In the 1980s, the activity of the foreign intelligence services concentrated on the specific political situation in Poland, i.e. the growing significance of the "Solidarity" social movement.

3) The specificity of the American intelligence activity against Poland was related to the composition of the residency staff, which was the largest in comparison to other Western countries. The wide range of these activities can be proved by the quantitative data of convictions for espionage in the years 1944-1984 (however, one has to bear in mind the factors mentioned earlier in the text, which led to the misinterpretation of these data). Analysing the data and the documents prepared by the Ministry of Internal Affairs, one should treat them with caution, as, frequently, the Polish counter-intelligence service used to classify the ordinary diplomatic practice and any contacts with foreigners as espionage threats. It is clearly visible in the language of the training materials concerned with "secret service methods of the intelligence activity" as well as in the documents on operational activities of the Security Service in relation to foreigners. The level of interest the USA had in Poland was mirrored in 
the classification of diplomatic posts, according to which Warsaw occupied the second place (the so-called Group "B") on the three-point scale. The CIA experienced spectacular defeats during their activity in Poland: supporting the Polish underground anti-communist organisation Freedom and Independence and the so-called Munich-Berg episode (both cases took place in the 1950s).

The text focuses only on selected issues related to the espionage activities against Poland. Similarly, the analysis of the problem has been based on selected sources, which has limited the research scope - however, it was not the aim of the author to present the espionage activity against Poland in a comprehensive way. In order to assess the real threat posed by the espionage activity, one should analyse the case of persons convicted for espionage in the period 1944-1989, as the available quantitative data, mentioned in the text, cannot constitute an explicit benchmark for the scale of espionage activity. The inaccuracies in the interpretation of data and variables, which can affect the evaluation of this phenomenon, have been pointed out in the text.

\section{Bibliography}

\section{References:}

A Catalogue of Persons Convicted for Espionage in Poland in the Period 1944-1984 (1986), Ministry of Internal Affairs, Warsaw.

A Memo of the Commander-in-Chief of the Citizens' Militia of 5 March 1963 (1963).

Certain Characteristics of the Intelligence Services Acting against Poland [Materials of the Ministry of Internal Affairs from the period 1960s-1980s; publication reference destroyed].

Gliński P. (1958), Legal Situation of Representatives of Foreign States and Staff Members of Diplomatic Posts in Poland (Sytuacja prawna przedstawicieli państw obcych oraz pracowników obcych przedstawicielstw w Polsce), Ministry of Internal Affairs.

Immunities and Privileges (Immunitety i przywileje) [Materials of the Ministry of Internal Affairs from the period 1960s-1980s; publication reference destroyed].

Information of the Director of the $2^{\text {nd }}$ Department at the Ministry of Internal Affairs on New Elements in the Practice of the American Intelligence Residency in Poland of 24 February 1988 (1988), in: P. Pleskot (2013b), A Diplomat, That Is a Spy? (Dyplomata, czyli szpieg?) Part II, IPN, Warsaw, pp. 607-615.

Materials of Department " $C$ " of the Voivodeship Office of Internal Affairs in Zielona Góra, No. 6007/III. 
Materials of Department "C" of the Voivodeship Office of Internal Affairs in Gdańsk, No. 11371/II.

Materials of Department "C" of the Voivodeship Office of Internal Affairs in Gdańsk, No. 15429/II, 7838/III.

Materials of the $2^{\text {nd }}$ Department of the " $C$ " Office of the Ministry of Internal Affairs, No. 4063/III.

Materials of the $2^{\text {nd }}$ Department of the " $C$ " Office of the Ministry of Internal Affairs, No. 6399/III.

Materials of the $2^{\text {nd }}$ Department of the " $C$ " Office of the Ministry of Internal Affairs, No. 7385/III.

Materials of the $2^{\text {nd }}$ Department of the " $C$ " Office of the Ministry of Internal Affairs, No. 7434/III.

Materials of the $2^{\text {nd }}$ Department of the "C" Office of the Voivodeship Office of Internal Affairs in Gdańsk, No. 6830/II.

Materials of the $3^{\text {rd }}$ Department of the $5^{\text {th }}$ Board of the Central Command Authority of the Military Internal Service, No. ZS-3977.

Materials of the $3^{\text {rd }}$ Department of the $5^{\text {th }}$ Board of the Central Command Authority of the Military Internal Service, No. ZS-4502.

Order No. 8/57 of 16 November 1957, (instructions attached) issued by the Commander-in-Chief of the Citizens' Militia.

Subversive and Political Activity (Działalność dywersyjno-polityczna) [Materials of the Ministry of Internal Affairs from the period 1960s-1980s; publication reference destroyed].

The Faces of the Security Service 1945-1990. Appointments to Managerial Posts of the Security Office in the Pomerania/Bydgoszcz, Torun, and Włocławek Voivodeships. A Catalogue of Personal Data (Twarze bezpieki 1945-1990. Obsada stanowisk kierowniczych Urzędu Bezpieczeństwa w województwach pomorskim/bydgoskim, toruńskim i włocławskim. Informator personalny) (2010), ed. M. Szymaniak, Institute of National Remembrance, Bydgoszcz-Gdańsk.

Uldanowicz J. (1960), Formalities with Respect to the Arrivals, Departures and Sojourns of Foreigners in Poland, in: Legal Situation of Foreigners in Poland, ed. J. Worobiec, Ministry of Internal Affairs - Human Resources and Training Department, Warsaw.

\section{Monographs:}

Affet J. (1978), Hostile Activity of Certain American Diplomats in Warsaw (Wroga działalność niektórych pracowników dyplomatycznych ambasady USA $w$ Warszawie), Legionowo.

Czubiński A. (1998), Europe in the $20^{\text {th }}$ Century, Publishing House: Wyd. Poznańskie, Poznań.

Dulles A. (2006), Craft of Intelligence: America's Legendary Spy Master On The Fundamentals Of Intelligence Gathering For A Free World, The Lyons Press, Guilford. 
Krajewski A. (2014), Contribution Paid to Poland. Colonel Ryszard Kukliński Tells His Story (Zastuga dla Polski. Pułkownik Kukliński opowiada swoja historię), E-bookowo, Warsaw.

Królikowski J. (2010), Generals and Admirals of the Polish Armed Forces 1943-1990 (Generałowie i admirałowie Wojska Polskiego 1943-1990), Vol. I: A-H, Torun.

Nurowska M. (2004), My Friend - Traitor (Mój przyjaciel zdrajca), J. Santorski \& Co., Warsaw.

Pawlikowicz L. (2004), The Secret Front of the Cold War. The Fugitives from the Polish Secret Service 1956-1964 (Tajny front zimnej wojny. Uciekinierzy z polskich stużb specjalnych 1956-1964), Oficyna Wydawnicza Rytm, Warsaw.

Piecuch H. (1996), Special Actions (Akcje specjalne), AW CB, Warsaw.

Piotrowski P. (ed.) (2006), The Security Apparatus in Poland. The Management Staff 1956-1975, Vol. 2, Institute of National Remembrance, Warsaw.

Piotrowski P. (ed.) (2008), The Security Apparatus in Poland. The Management Staff 1975-1990, Vol. 3, Institute of National Remembrance, Warsaw.

Pleskot P. (2013a), A Diplomat, That Is a Spy? (Dyplomata, czyli szpieg?), Part I, IPN, Warsaw.

Pleskot P. (2013b), A Diplomat, That Is a Spy? (Dyplomata, czyli szpieg?), Part II, IPN, Warsaw.

Prochwicz J. (1995), The Establishment of the Border Protection Troops (Powstanie Wojsk Ochrony Pogranicza), Warsaw.

Szwagrzyk K. (ed.) (2005), The Security Apparatus in Poland. The Management Staff 1944-1956, vol. 1, Institute of National Remembrance, Warsaw.

\section{Articles:}

Brzechczyn K. (2013), The Reception of the Disputes between the Positivism and Narrativism in the History of Polish Philosophy (Recepcja sporów pomiędzy pozytywizmem a narratywizmem w polskiej filozofii historii), "Ruch Filozoficzny", vol. LXX, No. 3.

Brzechczyn K. (2012), The Authenticity Problem of the Files and the Historical Narration Based Thereon. Several Methodological Notes (Problem wiarygodności teczek i opartej na nich narracji historycznej. Kilka uwag metodologicznych), "Pamięć i Sprawiedliwość. A Journal of the Institute of National Remembrance", vol. 20, no. 2.

Brzechczyn K. (2006), Between Science and Literature, That Is a Debate on the Status of History. An Attempt at Paraphrase (Między naukq a literatura, czyli debata nad statusem historii. Próba parafrazy), "Historyka. Studia Metodologiczne", vol. 36.

Jakimek-Zapart E. (2008), The Trial of the $4^{\text {th }}$ General Board of the Freedom and Independence (Proces IV Zarzadu Głównego WiN), "Biuletyn Instytutu Pamięci Narodowej", vol. 84-85, no. 1-2.

Koj E. (2007), The Board of the $2^{\text {nd }}$ General Staff of the Polish Armed Forces (An Operational Scheme in 1981-1990) [Zarzad II Sztabu Generalnego WP 
(Schemat funkcjonowania w latach 1981-1990)], "Biuletyn Instytutu Pamięci Narodowej", vol. 83, no. 12.

Łuczak A. (2011), The Agricultural Reform and the Repression Against the Polish Landed Gentry after the Year 1944 (Reforma rolna i represje wobec polskiego ziemiaństwa po roku 1944), "Biuletyn Instytutu Pamięci Narodowej”, vol. 124 , no. 3 .

Paczkowski A. (1993), On Stalin's Terror and Repression (O terrorze i represjach stalinowskich), "Wiadomości Historyczne", no. 1.

Paczkowski A. (1992a), The Security Apparatus in Poland (1994-1990) [Aparat bezpieczeństwa w Polsce (1944-1990)], "Mówią Wieki”, no. 5.

Paczkowski A. (1992b), The Polish Security Apparatus as the Extended Arm of the Soviet Structures (Polski aparat bezpieczeństwa jako kanat wplywów radzieckich), in: The Government Elites in Poland and the Social Structure in 1944-1956 (Elity wtadzy w Polsce a struktura spoleczna w latach 1944-1956), ed. P. Wójcik, ISNS UW, Warsaw.

Pióro T. (1999), The Getaways of the Polish Officers of the Polish People's Army in 1948-1990 (Ucieczki oficerów Ludowego Wojska Polskiego w latach 1948-1990), "Więzi”, vol. 494, no. 12.

Puchała F. (2012), Colonel Kuklinski's participation in the Game of the Intelligence Services of the Great Powers (Pułkownika Kuklinskiego udziat w grze wywiadów wielkich mocarstw), "Przegląd Historyczno-Wojskowy", no. 4.

Walenciak R. (2014), Double Agent (Podwójny agent), "Przegląd”, no. 7, http://www. przeglad-tygodnik.pl/pl/artykul/podwojny-agent, 15.10.2014.

Zając E. (2006), The Trace Remains in the Files (Ślad zostaje w aktach), "Pamięć i Sprawiedliwość. A Journal of the Institute of National Remembrance", vol. 60-61, no. 1-2.

\section{Other sources:}

A Catalogue of the Institute of National Remembrance of the Security Apparatus' Officers, (headword): Włodzimierz Ostaszewicz (2014), http://katalog.bip.ipn. gov.pl/showDetails.do?idx=OS\&katalogId=2\&subpageKatalogId=2\&page$\mathrm{No}=1 \&$ nameId=21979\&osobaId=51758\&, 15.10.2014.

\section{Działalność szpiegowska wobec Polski w dokumentach i analizach polskich służb specjalnych (1944-1989) - na przykładzie działalności wywiadowczej USA}

\section{Streszczenie}

Tekst omawia problem działalności szpiegowskiej wobec Polski w okresie 1944-1989. Analiza ta została wzbogacana danymi ilościowymi z okresu 1944-1984 w zakresie skazań za udział w obcym wywiadzie, działanie na jego rzecz oraz prze- 
kazywanie informacji. Problematykę szpiegostwa przedstawiono na przykładzie działalności USA, co zostało zobrazowane przykładami poszczególnych osób, które zostały skazane za działalność szpiegowską. W rozważeniu problemu badawczego posłużono się dokumentami i analizami opracowanymi przez Ministerstwo Spraw Wewnętrznych, głównie przeznaczonymi dla pracowników Służby Bezpieczeństwa i Milicji Obywatelskiej. W pracy podjęto się zweryfikowania następujących pytań badawczych: (1) W jakim stopniu charakter systemu społeczno-politycznego wpływał na liczbę skazań za szpiegostwo wobec Polski w analizowanym okresie 1944-1989?; (2) Jaki był poziom zainteresowania wywiadowczego obcych służb specjalnych Polską przed 1990 r.?; (3) Czy można wskazać na specyfikę działalności wywiadowczej USA przeciw Polsce?

Slowa kluczowe: szpiegostwo, szpiegostwo USA, działalność wywiadowcza, kontrwywiad, polski kontrwywiad, służby specjalne, bezpieczeństwo państwa 
